\title{
Intimate partner violence among health professionals: distribution by autonomous communities in Spain
}

\author{
Violencia por compañero íntimo en profesionales sanitarios: \\ distribución por comunidades autónomas españolas \\ Violência por parceiro íntimo em profissionais de saúde: \\ distribuiçãa por comunidades autónomas espanholas
}

Juan Manuel Carmona-Torres ${ }^{1,2}$, Beatriz Recio-Andrade ${ }^{3}$, María Aurora Rodríguez-Borrego ${ }^{1,3,4}$

How to cite this article:

Carmona-Torres JM, Recio-Andrade B, Rodríguez-Borrego MA. Intimate partner violence among health professionals: distribution by autonomous communities in Spain. Rev Esc Enferm USP. 2017;51:e03256. DOI: http://dx.doi.org/10.1590/S1980-220X2016049803256

${ }^{1}$ Instituto Maimónides de Investigación Biomédica de Córdoba, Córdoba, Spain.

${ }^{2}$ Universidad de Castilla la Mancha, Ciudad Real, Spain.

${ }^{3}$ Universidad de Córdoba, Córdoba, Spain.

${ }^{4}$ Hospital Universitario Reina Sofía de Córdoba, Córdoba, Spain.

\begin{abstract}
Objective: To determine the prevalence of intimate partner violence among health care professionals who work in the Spanish National Health System, according to the autonomous communities of Spain. Method: This was a descriptive cross-sectional multicenter study conducted with male and female health professionals (doctors, nurses, and nursing aides) in the different autonomous communities that are part of the Spanish National Health System. The following instruments were employed: among women, an intimate partner violence screening questionnaire; and among men, a questionnaire that screened for violence in the family environment. Results: A total of 1,039 health professionals participated in the study. Of these, $26 \%$ had suffered some type of abuse. Among the men, this prevalence was $2.7 \%$, while among the women, it was $33.8 \%$. There were differences in the prevalence of intimate partner violence among different autonomous communities, with the highest percentages in the Canary Islands. In terms of profession, $19.5 \%$ of the doctors had been exposed to intimate partner violence, while this percentage was $31 \%$ and $48.6 \%$ for nurses and nursing professionals, respectively. Conclusion: The results indicate the presence of intimate partner violence among healthcare personnel in most of the autonomous communities of Spain. The data demonstrate the need to implement action plans, both to support victims and to mitigate the problem.
\end{abstract}

\section{DESCRIPTORS}

Intimate Partner Violence; Health Personnel; Prevalence; Physicians; Nurses; Demography; Spain.

\section{Corresponding author:}

María Aurora Rodríguez Borrego

Universidad de Córdoba, Facultad de Medicina

y Enfermería, Departamento de Enfermería

Edificio Sur

Av. Menéndez Pidal s/n.

14071 - Córdoba - Spain

en1robom@uco.es
Received: 01/05/2017

Approved: 05/04/2017 


\section{INTRODUCTION}

Intimate Partner Violence (IPV) is the most common type of violence against women present in society, also affecting men to a lesser extent ${ }^{(1)}$. The World Health Organization has recognized IPV to be a public health and human rights issue $^{(2)}$. This phenomenon is present among all social groups and has been recently documented within the nursing category ${ }^{(3-6)}$. Healthcare services are a natural point of entry for possible victims ${ }^{(7-8)}$, and health professionals tend to represent their first point of contact with the system. Thus, it is especially relevant to study the prevalence of this issue among health personnel.

Recent studies have been conducted in Spain to analyze the prevalence of IPV in the general population, but only one study involving health professionals focused on nurses, who represent a particularly sensitive group. In that study, $33 \%$ of the investigated Andalusian nurses had been victims of abuse ${ }^{(5)}$.

The prevalence of IPV found among nurses in Andalusia was higher than in other studies conducted with the general Spanish population, which determined that $24.8 \%{ }^{(9)}$ of women who had resorted to primary health services (2006-2007) had suffered IPV at least once in their lives, and $15.1 \%$ had suffered IPV in the previous year, with greater prevalence in Ceuta and Melilla, followed by the community of Madrid and the Balearic Islands, and the lowest prevalence in Cantabria, Aragón and La Rioja ${ }^{(9)}$. This prevalence distribution of IPV seems to coincide with the distribution of gender-based violence in Spain ${ }^{(10)}$, given that the communities with the greatest number of reports per million women over the age of 15 were Melilla, Ceuta, and Balearic and Canary Islands.

Moreover, Europe presents a similar prevalence of IPV, reaching between $14 \%$ and $28 \%$ of the female population ${ }^{(11-12)}$.

Considering that IPV is a public health problem that affects the entire population, the research question was: To what extent does this issue personally affect health professionals who are responsible for providing health care to possible victims? Furthermore, the hypothesis have been proposed that experiencing situations of violence can result in failure to recognize the problem, explaining the low perception of IPV by health professionals ${ }^{(8,13-14)}$. Since health professionals play an important role in diagnosis of $\mathrm{IPV}^{(1,8,14-15)}$, the present study is of special relevance. Furthermore, cultural factors can be of interest as protective or predictive factors of IPV ${ }^{(9)}$.

Only one study has been conducted in Spain focused exclusively on nursing staff, and it demonstrated the severity of the problem: $33 \%$ of the studied female nurses had experienced $\mathrm{IPV}^{(3,5)}$. The high prevalence found in that study corroborates the international literature, such as in the United States ${ }^{(4)}$ and Jordan ${ }^{(6)}$, although there is a paucity of studies on the phenomenon among health professionals. Considering the above, it is important to determine the prevalence of IPV among health professionals, since health services usually assist IPV victims. Furthermore, these studies $^{(4,6)}$ have also emphasized that the experience of health professionals with IPV can help them to identify IPV and care for such patients.
Thus, the objective of the present study was to establish the prevalence of IPV in the different autonomous communities of Spain, among both male and female health professionals working for the Spanish National Health System.

\section{METHOD}

This was a descriptive cross-sectional multicenter study.

Participants were both male and female health professionals (physicians, nurses, and nursing aides) who worked for the Spanish National Health System, in both primary and specialized care services.

The sample size was calculated with Grammo software (version 7.11 March 2011) through population estimates using the baseline expected prevalence of $33 \%$, the rate found in the sample of Andalusian female nurses ${ }^{(5)}$; with $3 \%$ precision and $95 \%$ confidence level. This resulted in a minimum of 943 health professionals. Simple randomized sampling was used.

A total of 1,071 cases were recorded. However 32 were excluded, since to be included in the sample, the autonomous community had to present at least 20 cases for its data to be included in the analysis. Thus, the final sample consisted of 1,039 cases for which data was collected between October 2014 and April 2015.

The following instruments were used:

A questionnaire developed by Delgado et al. $(2006)^{(16)}$ and validated for women (reliability of 0.8688 and 0.7072 ). This questionnaire consists of 10 Likert-type close-ended questions that screen for physical, psychological, and sexual abuse. The scale of measurement was that used by the authors of the questionnaire, with modifications whenever recoding errors were identified ${ }^{(17)}$.

The men were given a questionnaire developed by Sherin et al. (1998) ${ }^{(18)}$ to screen for abuse, adapted to the Spanishspeaking population of the United States by Chen et al. $(2005)^{(19)},(100 \%$ sensitivity and $86 \%$ specificity). It consists of four Likert-type questions focused on detecting physical and verbal/psychological abuse. Item scores ranged between 1 and 5 , and total scores higher than 10 were considered indicative of abuse.

The first part of the data collection instrument consisted of the questionnaires mentioned above for women ${ }^{(17)}$ and men $^{(19)}$, while the second part consisted of a sociodemographic questionnaire that included a question about whether the participant had suffered or was suffering abuse, whether they had talked about it with anyone and with whom, and whether they had received support or treatment. The final part of the instrument provided an email address participants could use to contact the main researcher for a more in-depth interview.

The independent variables were: age, length of relationship in years, number of children and/or dependents, province, autonomous community, gender, profession, marital status, living situation, place of work, region of work, family income, social class of partner, presence of children and/or dependents over the age of 18 , in silence, in treatment, care provider.

Intimate partner violence was the dependent variable. Among the women, types of abuse were also analyzed, 
including latent dimensions of abuse (indirect interpretation of severity of abuse based on information obtained on different items of the questionnaire, classified as: no abuse, less severe abuse, and very severe abuse).

For data collection, the researchers contacted the health management of each autonomous community, requesting that they send the link for the online questionnaire to healthcare professionals under their supervision. An email was sent from the public service care management of the Spanish provinces to health professionals with an invitation to participate in the study. The link contained an online self-administered close-ended questionnaire which was completed anonymously through a web browser. The link contained a unique code that prevented multiple submissions.

Statistical data analysis was conducted using PASW Statistic 18 software. All hypothesis contrasting was bilateral.
Values with a confidence level of $95 \%(p<0.05)$ were considered statistically significant.

The protocol was approved by the Research Ethics Committee of the province of Córdoba, Spain, reference no. 2462, protocol 226. Research procedures were in accordance with the fundamental principles of the Declaration of Helsinki and the UNESCO Universal Declaration on Bioethics and Human Rights.

\section{RESULTS}

The data obtained from six autonomous communities were excluded, as they did not meet the inclusion criterion: Aragon (4 cases), Balearic Islands ( 12 cases), Extremadura (6 cases), La Rioja ( 2 cases) Navarra ( 2 cases) and Murcia (6 cases).

The study sample consisted of 1,039 health professionals, whose sociodemographic characteristics are presented in Table 1.

Table 1 - Sociodemographic variables of participants - Córdoba, Spain, 2015.

\begin{tabular}{|c|c|c|}
\hline Qualitative variables & Frequency $(\mathbf{N})$ & Percentage (\%) \\
\hline \multicolumn{3}{|l|}{ Gender } \\
\hline Man & 264 & 25.4 \\
\hline Woman & 775 & 74.6 \\
\hline \multicolumn{3}{|l|}{ Profession } \\
\hline Physician & 517 & 49.8 \\
\hline Nurse & 487 & 46.9 \\
\hline Nursing aide & 35 & 3.4 \\
\hline \multicolumn{3}{|l|}{ Place of work } \\
\hline Hospital & 364 & 35 \\
\hline Primary care & 675 & 65 \\
\hline \multicolumn{3}{|l|}{ Area of work } \\
\hline Urban & 869 & 83.6 \\
\hline Rural & 170 & 16.4 \\
\hline \multicolumn{3}{|l|}{ Children and/or dependents above the age of 18} \\
\hline Yes & 679 & 65.4 \\
\hline No & 360 & 34.6 \\
\hline \multicolumn{3}{|l|}{ Marital status } \\
\hline Single & 130 & 12.5 \\
\hline Married & 823 & 79.2 \\
\hline Separated or Divorced & 84 & 8.1 \\
\hline Widow & 2 & 0.2 \\
\hline \multicolumn{3}{|l|}{ Living situation } \\
\hline With husband/wife/current or previous partner & 774 & 74.5 \\
\hline With children & 100 & 9.6 \\
\hline With family of origin/partner's family & 93 & 9 \\
\hline Alone & 66 & 6.4 \\
\hline With friends & 6 & 0.6 \\
\hline \multicolumn{3}{|l|}{ Partner's social class } \\
\hline Class I & 347 & 33.4 \\
\hline Class II & 150 & 14.4 \\
\hline Class III & 151 & 14.5 \\
\hline Salaried employee & 186 & 17.9 \\
\hline Blue collar worker & 127 & 12.2 \\
\hline Unqualified worker & 78 & 7.5 \\
\hline \multicolumn{3}{|l|}{ Family income } \\
\hline Own wage & 270 & 26 \\
\hline Partner's wage & 20 & 1.9 \\
\hline Both & 749 & 72.1 \\
\hline Quantitative variables & Mean $(M)$ & Standard Deviation (SD) \\
\hline Age & 45.18 & 9.47 \\
\hline Children or dependents above the age of 18 & 1.25 & 1.09 \\
\hline Years of relationship with current or previous partner & 17.83 & 11 \\
\hline
\end{tabular}

Note: $(n=1,039)$ 
Of the 1,039 professionals interviewed, $25.9 \%$ had suffered some form of abuse. Among the men, this prevalence was $2.7 \%$. Among the women, this percentage was $33.8 \%$, with the most common type being psychological abuse (24\%), followed by psychological and sexual (4.4\%), psychological and physical (2.2\%), psychological, physical, and sexual (1.9\%), sexual (1\%), and physical (0.3\%). Regarding the severity of abuse among women, $27.1 \%$ of the cases were less severe, while $6.7 \%$ were exposed to very severe abuse. In terms of profession, $19.5 \%$ of the doctors, $31 \%$ of the nurses, and $48.6 \%$ of the nursing aides had been victims of IPV. Furthermore, most of the participants who had suffered IPV worked in primary care services (Table 2).

Table 2 - Intimate partner violence by profession and place of work - Córdoba, Spain, 2015.

\begin{tabular}{lccc}
\hline & \multicolumn{2}{c}{ Abuse? } & p \\
\cline { 2 - 3 } & No n (\%) & Yes n (\%) & \\
\hline Profession & & & \\
Physician & $416(80.5 \%)$ & $101(19.5 \%)$ & \\
Nurses & $336(69 \%)$ & $151(31 \%)$ & $<0.001$ \\
Nursing aide & $18(51.4 \%)$ & $17(48.6 \%)$ & \\
Place of work & & & \\
Hospital & $277(76.1 \%)$ & $87(23.9 \%)$ & 0.158 \\
Primary Care & $493(73 \%)$ & $182(27 \%)$ & \\
Area of work & & & \\
Urban & $663(74.7 \%)$ & $225(25.3 \%)$ & 0.177 \\
Rural & $130(71 \%)$ & $53(29 \%)$ & \\
\hline
\end{tabular}

It is worth noting that $25.3 \%$ of the participants who had suffered IPV had talked to someone about the incident. The most commonly sought out individuals were people of trust (26.5\%), followed by psychologists (23.5\%), health professionals (19.1\%), others (19.1\%), and both (health professional and person of trust) (11.8\%). $17.5 \%$ of the sample who had suffered IPV agreed to participate in an in-depth interview with anonymity ensured. Furthermore, $10.8 \%$ of the professionals who had suffered IPV were receiving some type of support or treatment.

Regarding the different autonomous communities, IPV was more prevalent in the Canary Islands (43.8\%). The lowest rates were found in the Basque Country (19\%) (Table 3).

In addition to the differences among IPV rates, there were also significant differences $(p=0.009)$ between marital status and autonomous community of participants, with the Community of Madrid presenting the highest percentage of married individuals. Significant differences were also found $(p<0.01)$ between place of work and autonomous community, with the highest percentage of primary health professionals working in the Community of Madrid. Significant differences $(p=0.03)$ were also found between gender and autonomous community, with Asturias presenting the highest proportion of women (Table 4).
Table 3 - Intimate partner violence in the different autonomous communities - Córdoba, Spain, 2015.

\begin{tabular}{|c|c|c|c|c|}
\hline \multirow{2}{*}{\multicolumn{2}{|c|}{ Community }} & \multicolumn{2}{|c|}{ Abuse? } & \multirow{2}{*}{ Total } \\
\hline & & No & Yes & \\
\hline \multirow{2}{*}{ Andalusia } & $\mathrm{N}$ & 182 & 48 & \multirow{2}{*}{230} \\
\hline & $\%$ & 79.1 & 20.9 & \\
\hline \multirow{2}{*}{ Asturias } & $\mathrm{N}$ & 16 & 6 & \multirow{2}{*}{22} \\
\hline & $\%$ & 72.7 & 27.3 & \\
\hline \multirow{2}{*}{ Canary Islands } & $\mathrm{N}$ & 27 & 21 & \multirow{2}{*}{48} \\
\hline & $\%$ & 56.3 & 43.8 & \\
\hline \multirow{2}{*}{ Cantabria } & $\mathrm{N}$ & 24 & 8 & \multirow{2}{*}{32} \\
\hline & $\%$ & 75.0 & 25.0 & \\
\hline \multirow{2}{*}{ Castilla-La Mancha } & $\mathrm{N}$ & 21 & 6 & \multirow{2}{*}{27} \\
\hline & $\%$ & 77.8 & 22.2 & \\
\hline \multirow{2}{*}{ Castile and León } & $\mathrm{N}$ & 23 & 14 & \multirow{2}{*}{37} \\
\hline & $\%$ & 62.2 & 37.8 & \\
\hline \multirow{2}{*}{ Catalonia } & $\mathrm{N}$ & 73 & 28 & \multirow{2}{*}{101} \\
\hline & $\%$ & 72.3 & 27.7 & \\
\hline \multirow{2}{*}{ Galicia } & $\mathrm{N}$ & 37 & 10 & \multirow{2}{*}{47} \\
\hline & $\%$ & 78.7 & 21.3 & \\
\hline \multirow{2}{*}{ Community of Madrid } & $\mathrm{N}$ & 320 & 115 & \multirow{2}{*}{435} \\
\hline & $\%$ & 73.6 & 26.4 & \\
\hline \multirow{2}{*}{ Basque Country } & $\mathrm{N}$ & 17 & 4 & \multirow{2}{*}{21} \\
\hline & $\%$ & 81 & 19 & \\
\hline \multirow{2}{*}{ Valencian Community } & $\mathrm{N}$ & 30 & 9 & \multirow{2}{*}{39} \\
\hline & $\%$ & 76.9 & 23.1 & \\
\hline
\end{tabular}

Table 4 - Distribution of gender according to autonomous communities - Córdoba, Spain, 2015.

\begin{tabular}{|c|c|c|c|c|}
\hline \multirow{2}{*}{ Community } & & \multicolumn{2}{|c|}{ Gender } & \multirow{2}{*}{ Total } \\
\hline & & Men & Women & \\
\hline \multirow{2}{*}{ Andalusia } & $\mathrm{N}$ & 74 & 156 & \multirow{2}{*}{230} \\
\hline & $\%$ & 32.2 & 67.8 & \\
\hline \multirow{2}{*}{ Asturias } & $\mathrm{N}$ & 3 & 19 & \multirow{2}{*}{22} \\
\hline & $\%$ & 13.6 & 86.4 & \\
\hline \multirow{2}{*}{ Canary Islands } & $\mathrm{N}$ & 17 & 31 & \multirow{2}{*}{48} \\
\hline & $\%$ & 35.4 & 64.6 & \\
\hline \multirow{2}{*}{ Cantabria } & $\mathrm{N}$ & 10 & 22 & \multirow{2}{*}{32} \\
\hline & $\%$ & 31.3 & 68.8 & \\
\hline \multirow{2}{*}{ Castilla-La Mancha } & $\mathrm{N}$ & 10 & 17 & \multirow{2}{*}{27} \\
\hline & $\%$ & 37 & 63 & \\
\hline \multirow{2}{*}{ Castile and León } & $\mathrm{N}$ & 8 & 29 & \multirow{2}{*}{37} \\
\hline & $\%$ & 21.6 & 78.4 & \\
\hline \multirow{2}{*}{ Catalonia } & $\mathrm{N}$ & 16 & 85 & \multirow{2}{*}{101} \\
\hline & $\%$ & 15.8 & 84.2 & \\
\hline \multirow{2}{*}{ Galicia } & $\mathrm{N}$ & 16 & 31 & \multirow{2}{*}{47} \\
\hline & $\%$ & 34 & 66 & \\
\hline \multirow{2}{*}{ Community of Madrid } & $\mathrm{N}$ & 90 & 345 & \multirow{2}{*}{435} \\
\hline & $\%$ & 20.7 & 79.3 & \\
\hline \multirow{2}{*}{ Basque Country } & $\mathrm{N}$ & 6 & 15 & \multirow{2}{*}{21} \\
\hline & $\%$ & 28.6 & 71.4 & \\
\hline \multirow{2}{*}{ Valencian Community } & $\mathrm{N}$ & 14 & 25 & \multirow{2}{*}{39} \\
\hline & $\%$ & 35.9 & 64.1 & \\
\hline
\end{tabular}

Finally, significant differences $(p<0.01)$ were also found between profession and autonomous community, with Andalusia presenting the highest number of nursing aides. 


\section{DISCUSSION}

The prevalence of IPV among health professionals of both genders ranged between $19 \%$ to $43.8 \%$. Furthermore, the prevalence of IPV found in the present study among health professionals working for the Spanish National Health System (25.9\% of the total sample, 33.8\% of women and $2.7 \%$ of men) was greater than that of the general population ${ }^{(9,11-12)}$. The last results of a study conducted by the Spanish Ministry of Health indicated that $24.4 \%$ had suffered some sort of abuse by their last partner ${ }^{(20)}$.

The prevalence of IPV among health professionals in the different autonomous communities of Spain found in the present study was higher than the prevalence reported in other studies conducted in Spain with the general population. The communities with the highest prevalence were the Canary Islands, Castile and León, and Catalonia, while in the general population, the communities with the highest prevalence were Ceuta and Melilla, the Balearic Islands, and the Community of $\mathrm{Madrid}^{(9)}$. The prevalence in this study did not coincide with the prevalence of reported genderbased violence according to the Ministry of Health, specifically the State Observatory on Violence against Women ${ }^{(10)}$. Thus, there seems to be a mismatch between the prevalence of violence and reported cases, in accordance with other studies conducted in Spain ${ }^{(21)}$.

The prevalence obtained was similar to that of other studies conducted with health professionals in other countries: a study in Jordan found that 59\% of the nurses had suffered psychological IPV ${ }^{(6)}$; a study in the United States found that $25 \%$ of the nurses had suffered IPV ${ }^{(4)}$.

The origin of the differences regarding prevalence of IPV in the different autonomous communities could be due to sociocultural differences or unequal development of gender equality and violence programs, among other causes ${ }^{(9,22)}$.

The percentage of IPV found among the women was similar to a previously mentioned study conducted with health professionals ${ }^{(5)}$. Of the different types of violence, psychological violence was the most common, similar to other studies conducted with the general population ${ }^{(5,9,23-24)}$.

No previous studies were found on IPV among Spanish men. Thus, the results are especially relevant because they demonstrate the existence of women who practice IPV against men, albeit to a lesser extent than that practiced by men towards women. This must be investigated, because society must be based on equality ${ }^{(25)}$. The prevalence of IPV among men was considerably lower than that found in other countries, such as Brazil, where one study found that 50\% of the participants had suffered IPV ${ }^{(26)}$. However, in the Brazilian study, the sample consisted of all types of men, while the present study only investigated health professionals.

Greater prevalence of IPV among health professionals than the general population is especially significant. These professionals work in services that are usually points of entry for victims of gender-based violence in general and intimate partner violence. Some studies have shown that female victims of violence first seek out psychological and psychiatric help, followed by health services, since they are the most valued of all the resources available to victims ${ }^{(20)}$. Thus, health services must be able to identify and respond to issues related to gender-based violence. However, studies have shown that health professionals frequently face various barriers in diagnosing the problem: high care demands, lack of training, lack of awareness of this health problem, etc. ${ }^{(1,27)}$.

Professional health education regarding IPV must be improved in order to first raise awareness among professionals about the issue as a public health problem that affects all groups. Second, they must be trained to approach possible victims and contribute to eliminating barriers that hinder the detection of IPV and establishing action and coordination protocols among different social health services ${ }^{(27-30)}$. A combination of professional training, knowledge about action protocols, and awareness among health professionals has been shown to increase IPV detection, mitigating health problems in abuse victims and reducing health costs ${ }^{(15,31)}$.

The limitations of the present study include the low number of participants in some communities, preventing generalization of the results, which must be considered with caution. Furthermore, it is possible that professionals who had suffered IPV were more motivated to participate in the study. Also, the rate of nonresponse could not be measured. And finally, the questionnaire required a mobile device or computer connected to the Internet, which may have influenced the higher participation of professionals in urban areas.

\section{CONCLUSION}

The findings of the present study indicate the presence of IPV among health professionals in most of the autonomous communities of Spain. The prevalence of IPV varied among communities, with the lowest rates in the Basque Country and Andalusia, and the highest in the Canary Islands and Castile and León. The prevalence of IPV in the studied health professionals was higher than that found in the general population. The data for some communities were excluded because of low response rates, requiring caution when interpreting the results. On the other hand, few studies have been conducted on the issue among health professionals, and those that exist were conducted with nurses. Thus, the results of the present research on the issue indicate a gap in the knowledge of IPV among health professionals.

\section{RECOMMENDATIONS FOR CLINICAL PRACTICE}

The data demonstrate the need to implement action and intervention plans, both to support victims and to mitigate the problem. Considering that health professionals also suffer from IPV, specific action plans must be implemented to provide them with specialized support. This could include improving professional education about IPV, enabling them to perceive when signs of abuse are present, including among themselves, so that early interventions could reduce case numbers and/or their consequences.

Considering the paucity of studies addressing the problem of IPV among health professionals, further studies are needed along this line of research in different countries with international samples. Health professionals who suffer IPV may have trouble identifying the problem among their patients. Health institutions must commit to resolving this severe problem, through measures such as education and victim support programs. 
RESUMO

Objetivo: Determinar a prevalência de violência por parceiro íntimo, nas comunidades autônomas espanholas, nos profissionais da saúde que trabalham no sistema de Saúde Pública do Estado espanhol. Método: Estudo multicêntrico, transversal, descritivo, realizado no sistema de Saúde Pública do Estado espanhol das diferentes comunidades autônomas. 1.039 profissionais da saúde de ambos os sexos (médicos, enfermeiros e auxiliares de enfermagem). Os instrumentos utilizados foram: para as mulheres, o questionário de deteç̧ão de maus-tratos a mulheres por seu par e, para os homens, o questionário de detecção da violência no âmbito da família. Resultados: Participaram do estudo 1039 profissionais de saúde. 26\% dos profissionais sofreram algum tipo de abuso por parceiro intimo. Para os homens, a prevalência de abuso foi de $2,7 \%$, enquanto no caso das mulheres foi de $33,8 \%$. Há diferenças na prevalência da violência por parceiro íntimo entre as diferentes comunidades autônomas, e nas Ilhas Canárias os valores foram mais elevados. Em relação à profissão, 19,5\% dos médicos/as, 31\% dos enfermeiros/as e 48,6\% dos auxiliares de enfermagem sofrem violência por parceiro íntimo. Conclusões: Os números mostram a presença de violência por parceiro íntimo em profissionais de saúde na grande maioria das comunidades autônomas da Espanha. Esses dados impulsionam a implementação de planos de ação para apoiar as vítimas e intervenções que diminuam o problema.

\section{DESCRITORES}

Violência por Parceiro Íntimo; Pessoal de Saúde; Prevalência; Médicos; Enfermeiras e Enfermeiros; Demografia; Espanha.

\section{RESUMEN}

Objetivo: Conocer la prevalencia de violencia por compañero íntimo, por comunidades autónomas, en los profesionales sanitarios que trabajan en el Sistema Sanitario Público del Estado Español. Método: Estudio descriptivo de tipo transversal multicéntrico realizado en las diferentes comunidades autónomas del Sistema Sanitario Público del Estado Español, con profesionales sanitarios de ambos sexos (médicos, enfermeras y auxiliares de enfermería). Como instrumentos se utilizó: para las mujeres el cuestionario de detección de malos tratos a mujeres por su pareja y para los hombres, el cuestionario de detección de violencia en el entorno familiar. Resultados: Participaron en el estudio 1039 profesionales sanitarios. El 26\% de los profesionales sufrió algún tipo de maltrato. En el caso de los hombres, la prevalencia de maltrato fue de 2,7\%, mientras que en el caso de la mujer fue de 33,8\%. Existen diferencias en la prevalencia de violencia por compañero íntimo entre las diferentes comunidades autónomas, presentándose las cifras más altas en las Islas Canarias. Respecto a la profesión, el 19,5\% de los médicos/as padecían violencia de compañero íntimo, el 31\% de los enfermeros/as y el 48,6\% de los auxiliares de enfermería. Conclusiones: Las cifras expuestas evidencian la presencia de violencia por compañero íntimo en el personal sanitario en la gran mayoría de las comunidades autónomas de España. Estos datos impelen la puesta en marcha de planes de actuación tanto de apoyo a las víctimas como de intervenciones que aminoren el problema.

\section{DESCRIPTORES}

Violencia de Pareja; Personal de Salud; Prevalencia; Médicos; Enfermeros; Demografía; España.

\section{REFERENCES}

1. Arroyo Sánchez G. Violencia de pareja y la responsabilidad del personal de salud. Med Leg Costa Rica. 2016;33(1):133-44.

2. Organización Panamerica de Salud; Organización Mundial de la Salud. Respuesta a la violencia de pareja y a la violencia sexual contra las mujeres. Directrices de la OMS para la práctica clínica y las políticas. Washington, DC: OPS; 2014.

3. Rodríguez-Borrego MA, Vaquero-Abellán M, Bertagnolli da Rosa L, Muñoz-Gamariz E, Redondo-Pedraza R, Muñoz-Alonso A. Intimate partner violence: study with female nurses. Aten Primaria. 2011;43(8):417-25.

4. Bracken MI, Messing JT, Campbell JC, La Flair LN, Kub J. Intimate partner violence and abuse among female nurses and nursing personnel: prevalence and risk factors. Issues Ment Health Nurs. 2010;31(2):137-48.

5. Rodríguez-Borrego MA, Vaquero-Abellán M, Bertagnolli da Rosa L. A cross-sectional study of factors underlying the risk of female nurses' suffering abuse by their partners. Rev Latino Am Enfermagem. 2012;20(1):11-8.

6. Al-Natour A, Gillespie GL, Wang LL, Felblinger D. A comparison of intimate partner violence between Jordanian nurses and Jordanian women. J Forensic Nurs. 2014;10(1):13-9.

7. Bradley F, Smith M, Long J, O'Dowd T. Reported frequency of domestic violence: cross sectional survey of women attending general practice. BMJ. 2002;324(7332):271.

8. Arguelles Vázquez R, Lorente Montalvo P, Esteva Cantó M. Care of victims of domestic violence in the Emergency Unit of a Health Centre. Aten Primaria. 2011;43(5):270-1.

9. Ruiz-Pérez I, Plazaola-Castaño J, Vives-Cases C, Montero-Pinar MI, Escriba-Aguir V, Jimenez-Gutierrez E, et al. Variabilidad geográfica de la violencia contra las mujeres en España. Gac Sanit. 2010;24(2):128-35.

10. España. Ministerio de Sanidad, Servicios Sociales e Igualdad. VII Informe del Observatorio Estatal de Violencia sobre la Mujer 2013. Madrid: MS; 2015.

11. Stene LE, Dyb G, Jacobsen GW, Schei B. Psychotropic drug use among women exposed to intimate partner violence: a population-based study. Scand J Public Health. 2010;38(5):88-95.

12. Rees S, Silove D, Chey T, Ivancic L, Steel Z, Creamer M, et al. Lifetime prevalence of gender-based violence in women and the relationship with mental disorders and psychosocial function. JAMA. 2011;306(5):513-21.

13. Andrade CJM, Fonseca RMGS. Considerations on domestic violence, gender and the activities of family health teams. Rev Esc Enferm USP [Internet]. 2008 [cited 2016 Dec 12];42(3):580-4. Available from: http://www.scielo.br/pdf/reeusp/v42n3/en_v42n3a24.pdf

14. Coll-Vinent B, Echeverría T, Farràs Ú, Rodriguez D, Millá J, Santiñà M. Intimate partner violence is not identified as a health problem by health care workers. Gac Sanit. 2008;22(1):7-10. 
15. Lozano C, Pina F, Torrecilla M, Ballesteros C, Pastor JD, Ortuño A. Formation and detection of gender violence in the healthcare profession. Rev Enferm UFSM. 2014;4(1):217-26.

16. Delgado A, Aguar M, Castellano M, Luna del Castillo JD. Validation of a Scale to Measure Ill-Treatment of Women. Aten Primaria. 2006;38(2):82-9.

17. Rodríguez-Borrego MA, Vaquero-Abellán M, Bertagnolli da Rosa L, Redondo-Pedraza R, Muñoz-Alonso A. Error in the interpretation of an abuse questionnaire. Aten Primaria. 2009;41(11):650-5.

18. Sherin KM, Sinacore JM, Li XQ, Zitter RE, Shakil A. HITS: a short domestic violence screening tool for use in a family practice setting. Fam Med. 1998;30(7):508-12.

19. Chen PH, Rovi S, Vega M, Jacobs A, Johnson MS. Screening for domestic violence in a predominantly Hispanic clinical setting. Fam Pract. 2005;22(6):617-23.

20. España. Ministerio de Sanidad, Política Social e Igualdad, Delegación Gobierno para la Violencia de Género. Macroencuesta de violencia contra la mujer 2015. Madrid: MS; 2015.

21. Vives C, Álvarez-Dardet C, Caballero P. Violencia del compañero íntimo en España. Gac Sanit. 2003;17(4):268-74.

22. World Health Organization. World report on violence and health. Geneva: WHO; 2002.

23. Meekers D, Pallin SC, Hutchinson P. Intimate partner violence and mental health in Bolivia. BMC Women's Health. 2013;13:28.

24. Jaen Cortés Cl, Rivera Aragón S, Amorin de Castro EF, Rivera Rivera L. Couple Violence in Women: Prevalence and Related Factors. Acta Invest Psicol. 2015;5(3):2224-39.

25. Aguilera Jiménez A, Barba Priego M, Fuentes Gutiérrez M, López Molina E, Villacreces Flores NM, García Ramirez JM. Violencia de la mujer hacia el hombre, $i$ mito o realidad? Rev Electr Invest Doc Creativa [Internet]. 2015 [citado 2016 dez.12];4(2):14-7. Disponible en: http://www.ugr.es/ reidocrea/ReiDoCrea-Vol.4-Art.2-Aguilera-Barba-Fuentes-Lopez-Villacreces-Garcia.pdf

26. Ferreira Cezario AC, Lage Carvalho L, do Carmo Lopes N, Moura Lourenço L. A violência entre parceiros íntimos sob a perspectiva de homens vítimas de suas parceiras no Brasil. Perspect Psicol. 2015;12(2):41-9.

27. Kulkarni SJ, Bell H, Rhodes DM. Back to basics essential qualities of services for survivors of intimate partner violence. Violence Against Women. 2012;18(1):85-101.

28. Sprague S, Madden K, Simunovic N, Godin K, Pham NK, Bhandari M, et al. Barriers to screening for intimate partner violence. Women Health. 2012;52(6):587-605.

29. Calvo G, Camacho R. La violencia de género: evolución, impacto y claves para su abordaje. Enferm Glob. 2014;13(33):424-39.

30. Beck JG, Clapp JD, Jacobs-Lentz, J, McNiff J, Avery M, Olsen SA. The association of mental health conditions with employment, interpersonal, and subjective functioning after intimate partner violence. Violence Against Women. 2014; 20(11):1321-37.

31. Pereira S, Vianna LAC. Improvement courses about violence prevention: the impact on health sector professionals. Rev Esc Enferm USP. 2014;48(2):315-20. DOI: http://dx.doi.org/10.1590/S0080--6234201400002000017 